\title{
Monitoring Brain Function during Neurosurgery
}

\author{
Nobuhiro Mikuni, M.D., Ph.D. ${ }^{1)}$ \\ 1) Department of Neurosurgery, Sapporo Medical University School of Medicine
}

To maintain the quality of life in patients undergoing neurosurgical treatment, it is essential to evaluate brain function pre- and intra- operatively. These evaluations which have been developed with studies in epilepsy are now essential in neurosurgery for brain tumors and vascular diseases. The goal of functional brain mapping followed by real-time function monitoring is to enable safe and effective surgery with better outcomes. Among multiple modern modalities for brain functional evaluations, we should consider each physiological aspect of these methods from a view point of functional recovery or compensation. Clinical usefulness and differences between intraoperative electrical stimulation of the motor cortex and subcortical fibers (i.e., pyramidal tracts) and voluntary movement to preserve affected or unaffected motor function during neurosurgery are also discussed.

(Received February 6, 2013 ; accepted February 19, 2013)

Key words : brain function, monitoring, brain tumor

Jpn J Neurosurg（Tokyo）22 : 519-524, 2013

\section{はじめに}

てんかん患者に対する覚醒下手術中に, 電気刺激によ る脳皮質機能局在を Penfield ${ }^{13)}$ が詳細に報告したこと によって, 近代の術中脳機能マッピング・モニタリング は始まる。当時は脳波加算などの技術はなく, コデイン などの鎮静剤を鎮痛剂に適宜組み合わせる術中の限られ た時間内での臨床症状中心の検査であった。その後脑波 計測・解析技術が発展し, 電気生理学的脳機能診断はて んかん患者での硬膜下電極留置中の信頼される検査と なった。その結果運動誘発電位（MEP）や体性感覚誘発 電位 $(\mathrm{SEP})$ 記録などの検査は 2000 年頃よりグリオーマ 摘出に応用されることとなり, 脳機能イメージングや ニューロナビゲーションをはじめとした手術支援機器が 同時期に導入された。現在では脳機能局在を提示した
MRI 上で位置関係を確認し，さらにその機能をモニタリ ングしながら病変摘出する方法が標準となりつつある.

\section{脳機能マッピング・モニタリングの 方法と意義}

局在が明らかにされている脳機能もあれば，いまだそ の局在は明らかでないものもある。前者にはたとえば単 純な運動に関わる一次運動野とそこから脊髄運動ニュー ロンに至る錐体路があり, 後者としては運動システムと してのネットワークでありその際に必要な意思に関わる 脳である。

運動機能に関して比較的解明が進んでいる単純な運動 に関する評価方法の中で術中モニタリングとしては皮質 電気（磁気）刺激による MEP, 運動時の脳電位活動, 随 
Pt. 1
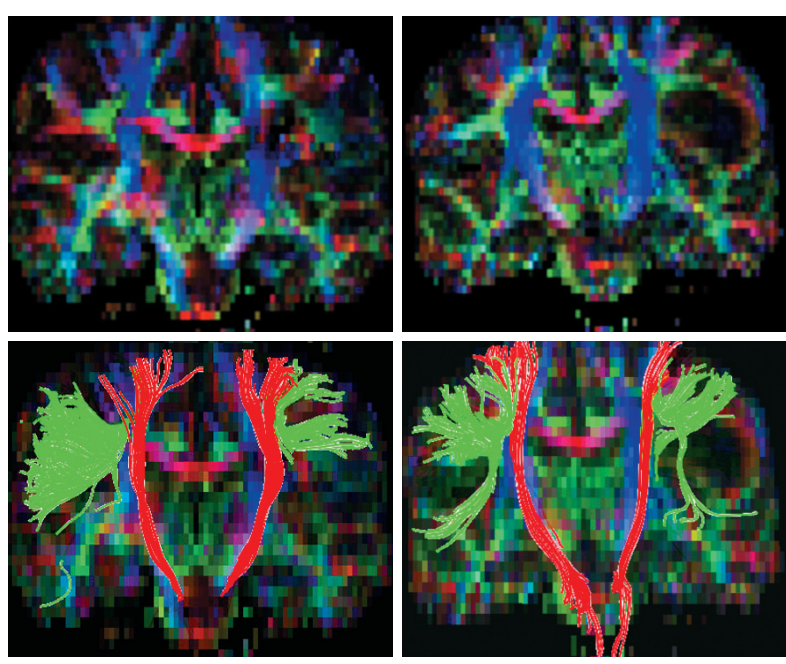

Fig. 1 Upper: Preoperative relative anisotropy maps for patients with brain tumor. Each of the anisotropy maps indicates the principal eigenvector (green: anterior-posterior, red: right-left, and blue: inferior-superior).

Lower: Coronal slices showing the fibers corresponding to the superior longitudinal fasciculus (SLF : green lines) and the pyramidal tracks (red lines) around the tumor. The SLF tracks anteroposteriorly through the corona radiata and the centrum semiovale, causing complicated fiber tracking of the upper extremity motor pathways near the tumors.

意運動，が挙げられる. MEP 記録法としては末梢筋の誘 発筋電図を記録する方法と, 脊䯣硬膜外電極を留置して 下行性誘発電位（direct wave）を記録する方法とがあ $3^{122) 1114)}$. 後者は全身麻酔下でも安定した記録が可能で 定量性に優れる。それぞれの検査最大の問題点はモニ夕 リング結果における手術中止・続行決定閾值が確立され ていないことにある。個々の病態による影響が関与して おり臨床的に完全な解決は困難ではあるが, 機能温存と いう安全性は得られてきた。

一方で，随意運動による活動電位と電気刺激による誘 発電位はその起源がまったく同一ではなく，たとえば随 意運動機能の変化は，純粋に皮質脊髄路のみの機能を反 映しているわけではなく，また電気刺激では指巧緻運動 を生じかつ評価（モニタリング）させることは困難であ り評価もできない，術前運動麻痺がある場合には術中信 頼できるモニタリング方法が予想困難である，以上のこ とから，さまざまなモニタリング検査方法の生理学的側 面から脳機能の可塑性や代償機構についても考慮するこ とが重要である。

\section{術中運動機能モニタリング}

術中脳機能モニタリングの中で最も一般的であるの は，グリオーマにおける運動機能モニタリングである.

グリオーマによる脳機能障害には腫瘍が脳機能をすで に浸潤損傷している，あるいは単に mass effect による, という 2 つの機序がある。腫瘍による組織破壊の強い部 分にはもはや脳機能は存在しないであろう。脳機能部位 近傍に腫瘍があっても神経脱落症状が出現していない場 合には，脳機能代償が生じている可能性は残るものの， 単に機能部位に対して腫瘍の物理的圧迫による解剖学的 シフトが生じたと考えられる。一方で悪性度の低いグリ オーマではしばしば脳機能部位内やその神経線維内に病 変が存在しているにも関わらず脱落症状は生じず，脳機 能局在の移動・代償の可能性以外に病変そのものが正常 な脳機能を有する場合がある。

脳機能部位近傍のグリオーマ摘出に際して各種術中脳 機能モニタリングを導入した場合の脳機能障害の経過に ついては以下のような報告がある。1 157 摘出例のうち $57 \%$ でほぼ全摘出を行い，一時的症状悪化は術前症状の

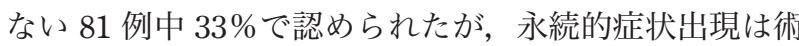
前症状のないもので $2.5 \%$, 術前症状のあるものでは $8 \%$ であった。術前より症状があった 76 例中 $33 \%$ で術後症 状は消失し，32\%で改善している3). 最近の報告では 309 例の脳機能部位近傍のグリオーマ手術で，21\%が手術中 に神経症状の悪化を認めそのうち $39 \%$ が 1 力月後にも 症状が続いている。 また，手術中に神経症状の悪化がな かった場合には $11 \%$ に 1 力月後神経症状が出現してい る. 全体で $17 \%$ に術後 1 力月後神経脱落症状の新たな出 現あるいは悪化を認めているが術後 3 力月後には全体 の $7 \%$ となっている ${ }^{5)}$. また，一次運動感覚野近傍の low grade glioma 摘出において 60 100\%に一過性運動麻痺 が生じたが，永続的なものはまったくなかったとする報 告もある1).

\section{自験例}

一次運動野近傍の脳腫瘍の摘出を覚醒下にて行った 74 例（年齢 15～69 歳）を対象とした術中運動モニタリ ングについて結果を示す。全例で術前拡散テンソル画像 による tractography を作成し術中 navigation 表示し，皮 質白質電気刺激を行っている。白質での電気刺激では neuronavigation 上の神経線維まで術中に $2 \mathrm{~cm}$ の距離と なれば刺激を開始した．錐体路は前後方向に走る上縦束 の影響を受けて上肢一次運動野からの神経線維が可視化 

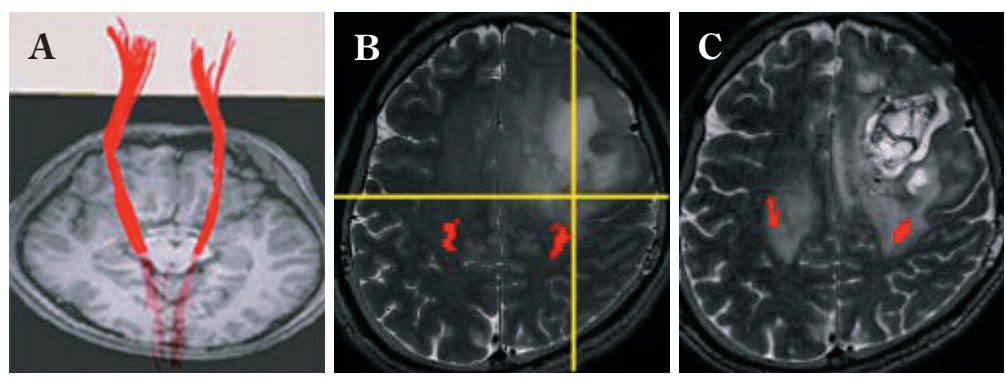

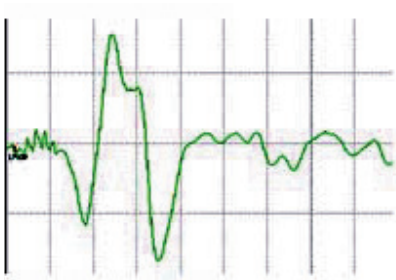

Cortex

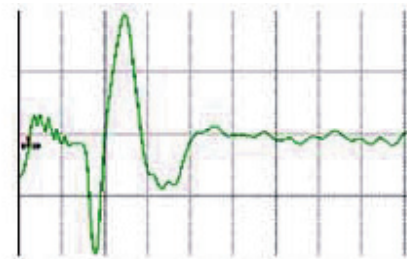

Subcortex
$20 \mu \mathrm{V}$

$10 \mathrm{msec}$

Fig. 2 Patients with a left fronto-parietal glioblastoma multiforme

A : Preoperative fiber tracking identified symmetrical pyramidal tracts (red lines) from the cortex to the cerebral peduncles.

B : Brain T2-weighted MRI revealed a hyperintense area in close proximity to the left pyramidal tract identified by fiber tracking (red). Cortical stimulation of the left precentral gyrus, which had been defined by somatosensory evoked potential (SEP), elicited a motor evoked potential (MEP) in the right abductor pollicis brevis muscle (Cortex). During removal of the tumor, subcortical stimulation elicited MEPs at the bottom of the tumor (intersection of the yellow lines in the intraoperative navigation image), $1 \mathrm{~cm}$ from the edge of the predicted pyramidal tract (red) (Subcortex). To avoid causing additional neurological deficits, no further resection was performed.

C : Postoperative T2-weighted MRI demonstrated preservation of the pyramidal tracts identified by fiber tracking (red).

困難であることに注意が必要である ${ }^{10)}($ Fig. 1).

結果 MEP 測定による一次運動野皮質のマッピング・ モニタリングは術前麻痺を伴わない症例では全例可能で あった。ただし，その電位は麻酔深度を維持してもコン トロールの 50 〜 $180 \%$ と変動があり，低下時手術中止と する指標にはならなかった。このため, 皮質 MEP を参 考に，かつ白質電気刺激による MEP が測定されれば摘 出は中止する, あるいは覚醒下にて運動能力評価を行い ながら摘出を続けるという方法により運動障害の発生は 認めなかつた ${ }^{11)}$ (Fig. 2).

術前より運動麻痺を認め MEG や fMRI の検査が困難 な症例では tractography と術中 MEP 検出に相関があ り, tractography が術前に抽出困難な症例では覚醒下手 術による運動機能評価を行い症状悪化させることなく十 分な病変摘出が可能であった (Fig. 3 $)^{9)}$.
運動麻痺をすでに生じている運動野近傍の病変では解 剖学的影響のために MRI での中心溝の同定が困難にな るだけではなく錐体路 tractography の抽出不良をきたす 場合がある。また，生理学的影響により MEP と tractography の信頼性が低下し, 術前検査としての fMRI, PET, 脳磁図では検査に必要な随意運動そのものが実行 困難となる。通常の手術のように脳電気刺激での運動評 価を予定していても，手術中に初めて MEP が記録でき ないことがわかると全身麻酔では信頼できる機能評価な しの手術操作を余儀なくされる。もちろん, MEP の反応 が得られる場合もあるが，術前にその有無を予想するあ るいは MEP に代わる運動機能評価方法を用意しておく ことが望まれる。

運動麻痺のある脳腫瘍患者 10 名で術前の各種運動機 能評価方法 (筋力, fMRI, 脳磁図, 錐体路 tractography) 

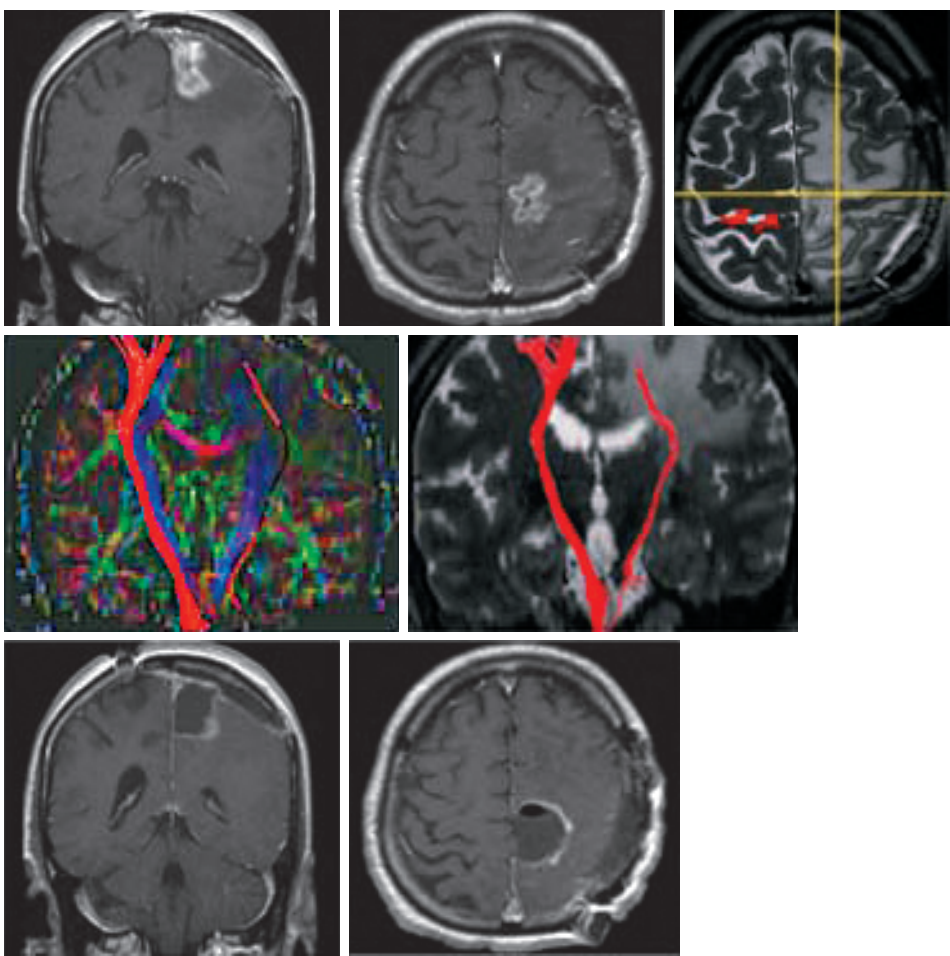

Fig. 3 Fiber tracking of the pyramidal tracts was disrupted in a 67-year-old man with a left frontoparietal glioblastoma multiforme

Upper: Preoperative T2-weighted MRIs identified a focus of hyperintensity in the left perirolandic region with gadolinium enhancement of the rostral precentral cortex. Stimulation of the left cortex rarely elicited weak MEP responses on the right abductor pollicis brevis muscle. Subcortical stimuli, even on the approximated posterior bank of the precentral gyrus on neuronavigation (intersection of the yellow lines in the intraoperative navigation image), did not elicit MEPs.

Middle: A relative anisotropy map indicated the principal eigenvector (green: anterior-posterior, red : right-left, and blue: inferior-superior). Fiber tracking of the left pyramidal tract (red lines) near the tumor was disrupted during its course to the cortex.

Lower: Postoperative MRIs with gadolinium enhancement.

と術中 MEP の有無を比較した結果, 術前の tractography が術中 MEP 検出の有無と相関していた. 大脳脚か ら脳表に至るまで腫瘍近傍においても錐体路 tractography が抽出できた症例では皮質白質ともに MEP は記録 可能であったが，抽出不良の場合には信頼できる MEP は記録できず，覚醒下での随意運動が運動機能評価とし て有用であった ${ }^{9)}$. 虚血性病変での報告 ${ }^{7)}$ と同様に, 術前 運動麻痺の程度と錐体路 tractography の抽出には必ずし も相関は認められず，手術前の運動障害の程度によって 術中の MEP 誘起を予測することは危険を伴う.

\section{覚醒下手術と脳機能可塑性}

覚醒下手術中の脳機能局在診断は病変を持つ患者とい う特殊な病態下での検査ではあるが，摘出に伴う局所症 状やその機能代償について考察することが可能である. 一次運動野ではない運動関連野の障害に関して，たとえ ば補足運動野の摘出で一過性運動障害が高率に生じる が，覚醒下手術を受けた場合手術後数時間以降になって 症状が出現するという ${ }^{4)}$ 。また，陰性運動野の摘出直後 に一過性の巧緻運動障害を生じ機能代償に頭頂葉の関与 が考えられる 。電気刺激による誘発電位や随意活動に 伴う脳活動電位を測定し，その結果を覚醒下術中および 
術後の機能回復経過と併せて脳機能ネットワークを包括 的に研究することで, 脳機能代償の仕組みの解明が進む ことが期待される ${ }^{10)}$.

\section{おわりに}

脳機能モニタリングについて，脳神経外科手術にとつ ての臨床的意義の観点から特に運動機能を中心に解説し た。機能異常をマッピング・モニタリングして治療する, という機能的脳神経外科領域から始まった脳機能マッピ ング・モニタリングは医療機器・技術進歩とともに ニューロサイエンスを切り開いてきた。現在では多様な 生理機能の側面から脳機能システム研究が可能になり, ブレインマシンインターフェースへの応用も始まってい る. 脳神経外科学, 麻酔科学, 高次脳機能研究, リハビ リテーションの融合によって運動感覚や言語だけではな く認知などの高次機能についても保護する手術支援とし て発展し, 術中結果を通じてさらにダイナミックなヒト 脳機能診断が進むと期待される。

\section{文 献}

1) Bertani G, Fava E, Casaceli G, Carrabba G, Casarotti A, Papagno C, Castellano A, Falini A, Gaini SM, Bello L: Intraoperative mapping and monitoring of brain functions for the resection of low-grade gliomas: technical considerations. Neurosurg Focus 27: E4, 2009.

2) Cedzich C, Taniguchi M, Schafer S, Schramm J: Somatosensory evoked potential phase reversal and direct motor cortex stimulation during surgery in and around the central region. Neurosurgery 38: 962-970, 1996.

3) Danks RA, Aglio LS, Gugino LD, Black PM : Craniotomy under local anesthesia and monitored conscious sedation for the resection of tumors involving eloquent cortex. $J$ Neurooncol 49: 131-139, 2000.

4) Duffau H, Lopes M, Denvil D, Capelle L: Delayed onset of the supplementary motor area syndrome after surgical resection of the mesial frontal lobe: a time course study using intraoperative mapping in an awake patient. Stereotact Funct Neurosurgery $\quad \mathbf{7 6}: 74-82,2001$.
5) Kim SS, McCutcheon IE, Suki D, Weinberg JS, Sawaya R, Lang FF, Ferson D, Heimberger AB, DeMonte F, Prabhu SS : Awake craniotomy for brain tumors near eloquent cortex: correlation of intraoperative cortical mapping with neurological outcomes in 309 consecutive patients. Neurosurgery 64: 836-846, 2009.

6) Kombos T, Suess O, Ciklatekerlio O, Brock M: Monitoring of intraoperative motor evoked potentials to increase the safety of surgery in and around the motor cortex. $J$ Neurosurg 95: 608-614, 2001.

7) Lee JS, Han MK, Kim SH, Kwon OK, Kim JH: Fiber tracking by diffusion tensor imaging in corticospinal tract stroke: Topographical correlation with clinical symptoms. Neuroimage 26: 771-776, 2005.

8) Mikuni N, Ohara S, Ikeda A, Hayashi N, Nishida N, Taki J, Enatsu R, Matsumoto R, Shibasaki H, Hashimoto N: Evidence for a wide distribution of negative motor areas in the perirolandic cortex. Clin Neurophysiol 117:33-40, 2006.

9) Mikuni N, Okada T, Enatsu R, Miki Y, Urayama S, Takahashi JA, Nozaki K, Fukuyama H, Hashimoto N : Clinical significance of preoperative fiber-tracking to preserve the affected pyramidal tracts during the resection of brain tumors in patients with preoperative motor weakness. $J$ Neurol Neurosurg Psychiatry 78: 716-721, 2007.

10) Mikuni N, Okada T, Enatsu R, Miki Y, Urayama S, Takahashi JA, Nozaki K, Fukuyama H, Hashimoto N: Using preoperative fiber tracking to preserve pyramidal tracts during brain tumor removal. Nat Clin Pract Neurol 3: 301-302, 2007.

11) Mikuni N, Okada T, Enatsu R, Miki $Y$, Hanakawa $T$, Urayama S, Kikuta K, Takahashi JA, Nozaki K, Fukuyama $\mathrm{H}$, Hashimoto $\mathrm{N}$ : Clinical impact of integrated functional neuronavigation and subcortical electrical stimulation to preserve motor function during the resection of brain tumors. J Neurosurg 106: 593-598, 2007.

12) Mikuni N, Okada T, Nishida N, Taki J, Enatsu R, Ikeda A, Miki Y, Hanakawa T, Fukuyama H, Hashimoto N: Comparison between motor evoked potential and fiber tracking for estimating pyramidal tracts near brain tumors. J Neurosurg 106: 128-133, 2007.

13) Penfield $W$, Jasper $H$ : Epilepsy and the functional anatomy of the human brain. Boston, Little Brown, 1954.

14) Pouratian N, Cannestra AF, Bookheimer SY, Martin NA, Toga AW: Variability of intraoperative electrocortical stimulation mapping parameters across and within individuals. J Neurosurg 101: 458-466, 2004. 
要

旨

術中脳機能モニタリング

三國 信啓

医療機器やコンピュータの進歩に伴い, 術前術中脳機能検査技術はこの十数年間に飛躍的な進歩を 遂げてきた．これらの技術はてんかんにおける研究を通じて発展し, 現在では脳腫瘍, 血管障害を含 めた脳神経外科手術全般において重要な位置を占めるようになっている. “マッピング”された脳機 能を “モニタリング”しながら手術を安全かつ効果的に行う.ささまざまな脳機能研究の中で, 病態下 での脳神経外科術中モニタリングを脳の生理学的側面から捉え, 機能代償・回復という視点をもつこ とが重要である. 本稿では最も一般的な運動機能モニタリングについて, 電気刺激による誘発電位と 随意運動の差異についての自験例を含めて解説した．今後さまざまな脳機能検査がさらに簡便に使用 できるようになり，術中の手術方針決定には生理学的考察により検査結果を理解できることが必要と 考える. 